\begin{tabular}{l|l|l|l} 
Case Reports in & Case Rep 0phthalmol 2010;1:20-23 & Published online: June 11, 2010 & $\begin{array}{l}\text { ○ 2010 S. Karger AG, Basel } \\
\text { ISSN 1663-2699 } \\
\text { wwww.karger.com/cop }\end{array}$ \\
& & & \\
\hline
\end{tabular}

\title{
Over-Treated Corneal Abscess May Be Toxic Keratopathy
}

\author{
P. Rubino J.G. Orsoni A. Rampini P. Mora \\ Institute of Ophthalmology, University of Parma, Parma, Italy
}

\section{Key Words}

Toxic keratopathy $\cdot$ Corneal abscess $\cdot$ Corneal mycosis

\begin{abstract}
Background/Aims: Keratitis, especially when long-standing and unresponsive to common antimicrobial treatment, leads to a suspicion of fungal aetiology.

Methods: Photographically documented case report.

Results: A 65-year-old man with diabetes was referred for corneal abscess unresponsive to antibiotic and antifungal treatment lasting 6 weeks. Corneal biopsy was performed following a 72-hour washout for identification of bacteria and fungi. Previously administered drops were withdrawn and only preservative-free artificial tears were maintained. Neither bacteria nor fungi were cultured. After 2 weeks, the clinical situation had conspicuously improved.
\end{abstract}

Conclusion: Over-treatment of corneal affections fearing mycosis may lead to toxic keratopathy.

Toxic keratopathy due to varying aetiologies has been well known for decades [1-4]. Ophthalmologists, desperate when faced by long-standing ocular inflammation unresponsive to treatment, tend to over-treat corneal affections with every conceivable therapy. Particularly worrying is fungal keratitis. We describe here a typical example of this situation.

\section{Case Report}

A 65-year-old Italian farmer with orally treated diabetes was referred to us for a left eye corneal abscess unresponsive to topical antibiotic and anti-inflammatory treatment lasting 6 weeks. The patient had suffered a cow-tail trauma 20 years earlier in the same eye. This gave rise to a central corneal ulcer and poor vision (20/160, measured with the Early Treatment of Diabetic Retinopathy Study (ETDRS) chart). It resulted in central leucoma with mild vascularisation. After a more recent trauma, the patient was hospitalised due to a corneal abscess in the same eye. Owing to the lack of response to various antimicrobial local drugs, i.e. tobramycin $0.3 \%$ drops 8 times/day and ampicillin $0.8 \%$ drops 4 times/day, even associated with steroid eyedrops, i.e. dexamethasone $0.3 \%$ eyedrops, all with preservatives, fungal infection was suspected despite negative corneal scraping. This suspicion was (psychologically) strengthened in the treating ophthalmologist for three reasons: the corneal ulcer had 


\begin{tabular}{l|l|l|l} 
Case Reports in & Case Rep 0phthalmol 2010;1:20-23 & Published online: June 11, 2010 & $\begin{array}{l}\odot 2010 \text { S. Karger AG, Basel } \\
\text { ISSN 1663-2699 } \\
\text { www.karger.com/cop }\end{array}$ \\
\hline
\end{tabular}

been caused by a mild agricultural trauma, the patient was diabetic, and the clinical history and the corneal picture were suggestive of fungal keratitis. Before referral to us, systemic and local ketoconazole $0.4 \%$ ( 3 times/day) and topic levofloxacin $0.5 \%$ ( 4 times/day) had been unsuccessfully administered for two weeks. Thus, we were asked to perform extreme antifungal treatment with corneal intrastromal voriconazole [5]. At admission, severe conjunctival hyperhaemia with $360^{\circ}$ corneal neovascularisation, a central, ulcerative, abscess-like keratopathy with a satellite lesion, and hypopion were evident (fig. 1). A corneal biopsy was performed following a 72-hour washout for identification of bacteria and fungi. Previously administered drops were withdrawn and preservative-free artificial tears and cycloplegics were given instead. Neither bacteria nor fungi were found. Over the next 2 weeks, the clinical picture improved and resolved 4 weeks later: conjunctival hyperhaemia was significantly reduced, hypopion and corneal infiltrates had disappeared, and the corneal stroma appeared more transparent (fig. 2). The clinical picture was similar to the one described clinically after healing from the coil trauma.

\section{Comment}

In clinical practice, the ophthalmologist is often tempted to treat ocular inflammation without a working diagnosis and microbiological confirmation, especially if coping with a poorly cooperative patient. In this specific case, very probably, an asymptomatic central corneal epithelial defect persisted after the earlier cow-tail trauma. Clinical signs of toxic keratopathy are usually so nonspecific that a diagnosis can only be confirmed by withdrawing suspected medications and drops with preservatives.

Fig. 1. Aspect of the RE at admission.

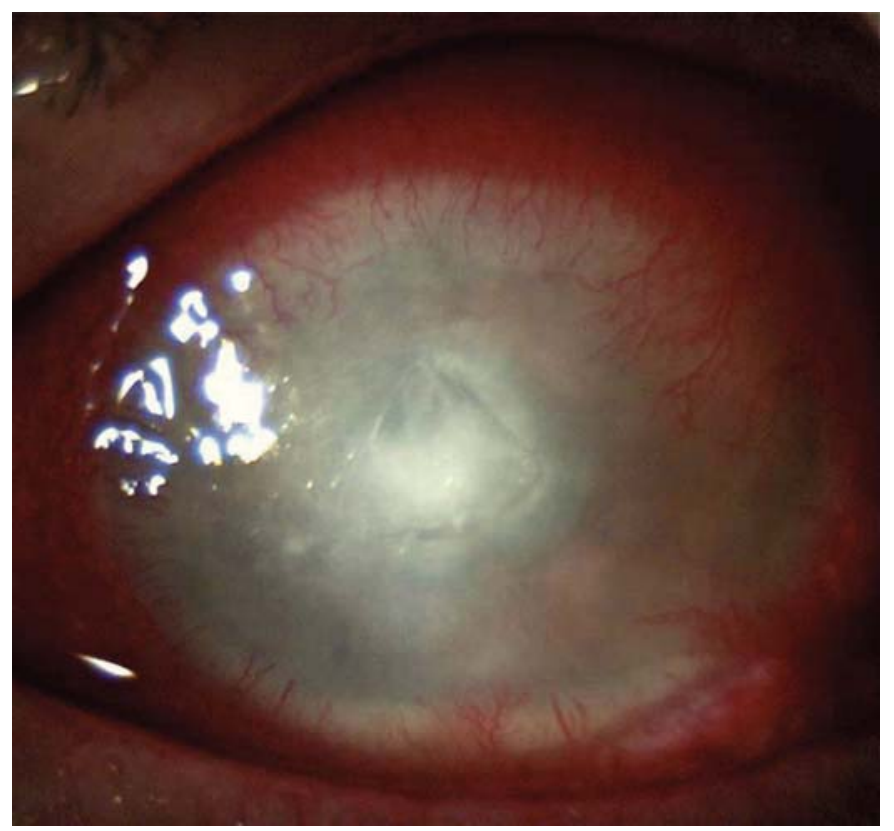




\begin{tabular}{l|l|l|l}
$\begin{array}{l}\text { Case Reports in } \\
\text { Ophutinology }\end{array}$ & $\begin{array}{l}\text { Case Rep 0phthalmol 2010;1:20-23 } \\
\text { D0I: } 10.1159 / 000315397\end{array}$ & Published online: June 11, 2010 & $\begin{array}{l}\text { ○ 2010 S. Karger AG, Basel } \\
\text { ISSN 1663-2699 } \\
\text { www.karger.com/cop }\end{array}$ \\
\hline
\end{tabular}

Fig. 2. Aspect of the RE four weeks after admission.

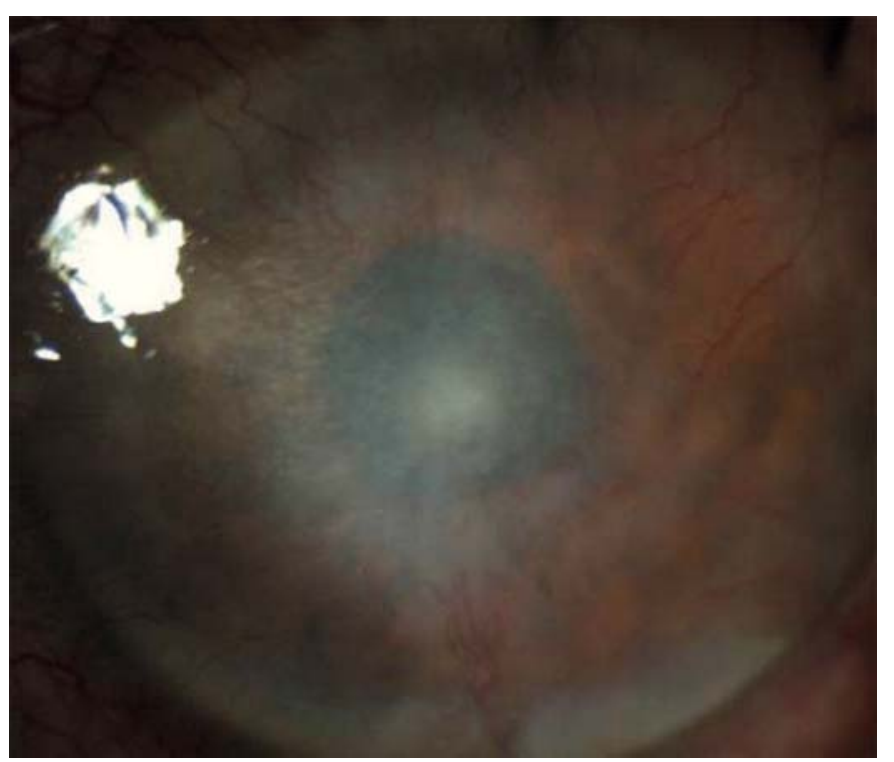




\begin{tabular}{|c|c|c|c|}
\hline $\begin{array}{l}\text { Case Reports in } \\
\text { Oplualmology }\end{array}$ & $\begin{array}{l}\text { Case Rep Ophthalmol 2010;1:20-23 } \\
\text { D0I: } 10.1159 / 000315397\end{array}$ & Published online: June 11, 2010 & $\begin{array}{l}\text { (c) } 2010 \text { S. Karger AG, Basel } \\
\text { ISSN } 1663-2699 \\
\text { www.karger.com/cop }\end{array}$ \\
\hline
\end{tabular}

\section{References}

1 Wilson FM: Adverse external ocular effects of topical ophthalmic therapy: an epidemiological, laboratory and clinical study. Trans Am Ophthalmol Soc 1983;81:854-965.

2 Schwab JR, Abbott Rl: Toxic ulcerative keratopathy: an unrecognized problem. Ophthalmology 1989;96:1187-1193.

3 Dart JK: Corneal toxicity: the epithelium and stroma in iatrogenic and factitious disease. Eye 2002;17:886-892.

-4 Sun XG: Pay attention to drug-induced keratopathy. Zhonghua Yan Ke Za Zhi 2009;45:97-99.

-5 Prakash G, Sharma N, Goe M, Stitiyal J, Vaipayel RB: Intrastromal injection of voriconazole in the management of deep recalcitrant fungal keratitis. Am J Ophthalmol 2008;146:56-59. 